\title{
THE RELATIONSHIP BETWEEN FAMILY FUNCTIONS AND RISKY SEXUAL BEHAVIOR IN INDONESIA IN 2018: A PMA DATA ANALYSIS
}

\author{
Diah Puspita Sari ${ }^{1}$, Mario Ekoriano ${ }^{2}$, Aditya Rahmadhony ${ }^{3}$ \\ 1,2,3 The National Population and Family Planning Board, Indonesia \\ Corresponding Author: Diah Puspita Sari \\ E-mail: dihaziriz@yahoo.com
}

\begin{abstract}
This analysis aimed to examine the relationship between family development and risky adolescent sexual behavior in Indonesia. The data were taken from the 2018 Performance and Accountability Survey with a family and adolescent questionnaire; thus, the relationship between parents and adolescents could be identified. The statistical analysis methods used were descriptive and inferential analyses, with the unit of analysis being 15,556 teenagers who dated. The results of the logistic regression analysis (Model 1) by using all the independent variables simultaneously found that sexual risk behavior was mostly found in in boys, age categories 20-24 years, and participants who never had access to PIK-R. Risky sexual behavior was also dependent on whether participants agreed to have relations sexual before marriage, and also the level of education of their parents. The logistic regression analysis (Model 2) found residence, gender, level of adolescent education, age categories, agreement to have sexual relations before marriage, age groups of head of family, gender of head of family, education level of head of family, work status of head of family, economic status, and the activeness of the BKR activities contributed to adolescents committing risky sexual behaviors.
\end{abstract}

Keywords: risky sexual behavior, teenagers, family functions

\section{ABSTRAK}

Analisis ini bertujuan untuk menguji hubungan fungsi keluarga dengan perilaku berisiko remaja di Indonesia. Data yang digunakan pada analisis ini adalah Survei Kinerja dan Akuntabilitas (SKAP) tahun 2018 dengan menggunakan kuesioner keluarga dan kuesioner remaja, sehingga keterkaitan orang tua remaja dan remajanya dapat diketahui. Analisis statistik yang digunakan menggunakan penyajian secara deskriptif dan inferensial dengan unit analisis adalah remaja yang pernah mempunyai pacar sebanyak 15.556 remaja. Hasil analisis regresi logistik (Model 1) dengan menggunakan seluruh variabel independen secara simultan menemukan, perilaku seksual berisiko terjadi pada anak laki-laki, kategori umur 20-24 tahun, tidak pernah akses PIK-R, persetujuan dalam melakukan hubungan seksual sebelum menikah, dan tingkat pendidikan orang tua. Sedangkan analisis regresi logistik pada (Model 2) ditemukan wilayah tempat tinggal, jenis kelamin, tingkat pendidikan remaja, kategori umur remaja, remaja yang setuju melakukan hubungan seksual sebelum menikah, kelompok umur orang kepala keluarga, jenis kelamin kepala keluarga, tingkat pendidikan kepala keluarga, status pekerjaan kepala keluarga, dan status ekonomi cenderung melakukan perbuatan berisiko seksual remaja.

Kata kunci: perilaku berisiko seksual, remaja, fungsi keluarga

Received: August 19, 2020

Accepted: November 4, 2020

\section{INTRODUCTION}

The main issues in sexual health and adolescents' reproductive health include sexual development and sexuality, sexually transmitted diseases, HIV/AIDS, and unwanted and unsafe pregnancies. Many factors underlie unhealthy sexual development in teenagers, including their social environment. These include individual characteristics, namely age, sex, marital status, and residence. Contextual factors such as poverty and unemployment, gender and ethnical discrimination, and the impact of social change towards family and community also contribute to unhealthy sexual development (UNICEF, 2006). 
Family members play the main role in shaping teenagers' sexual behavior through various parenting practices in communicating sexual matters with adolescents. Various research has proven that the more parental monitoring done towards teenagers, the less likely they will commit sexual behavior in the future (Guha, 2013).

When teenagers begin puberty, naturally, they will experience increasing sex drive caused by their reproduction organs starting to develop. It then becomes possible for teenagers to encounter various risks related to their reproductive health. Sexual behavior in teenagers includes risky behaviors in four stages, namely touching (hand-holding to hugging), kissing, groping/fondling, and finally, sexual intercourse or the penis penetrating the vagina (Kinsey et al., 1998). Activities related to risky sexual behaviors commonly occur in teenagers who are actively partaking in other forms of risky behaviors such as smoking, drinking alcohol, taking drugs, and committing juvenile delinquency (Ensminger, 1987).

Based on data from the Indonesian Demographic Health Survey (IDHS) of adolescents' reproductive health, there has been an increase in teenagers' sexual behaviors. Less than $1 \%$ of female teenagers committed sexual intercourse in 2012 (BKKBN, 2013), but this number increased to $2 \%$ based on the 2017 IDHS of adolescents' reproductive health. Male teenagers experienced a decrease in sexual behavior, with as many as $8.3 \%$ committing intercourse in 2012 (The National Population and Family Planning Board, 2013) and a decrease to $7.6 \%$ based on the 2017 IDHS concerning adolescents' reproductive health (BKKBN, 2018b). The results of the Performance, Monitoring, and Accountability Survey (PMA) 2018. However, showed a decrease in sexual behavior in teenagers with romantic partners $(2.1 \%)$ compared to the results of the 2017 MediumTerm National Development Plan Survey (MTNDPS) $(8.1 \%)$.

The results of the 2012 IDHS showed as many as $30 \%$ of male teenagers and $6 \%$ of female teenagers sexually aroused their partners. Furthermore, $48 \%$ of male teenagers and $30 \%$ of female teenagers did oral kissing, and $80 \%$ of male teenagers and $72 \%$ of female teenagers held hands with their partners. According to the 2017 IDHS, dating behavior in terms of oral kissing increased to as many as $50 \%$ of teenagers (BKKBN, 2018a).

Research administered in Southwestern Ethiopia revealed that $31.3 \%$ of teenagers had romantic partners and actively engaged in sexual relationships (Behulu Anteneh, and Aynalem, 2019). Eggleston, Jackson, and Hardee (1999) stated $6 \%$ of girls and $60 \%$ of boys committed sexual intercourse in Jamaica. Both male and female teenagers possessed inaccurate knowledge about reproduction health and behavior.

Studies related to teenagers' risky sexual behaviors administered in Indonesia included one by Dewi (2012) in the Depok, Pasir Gunung Selatan sub-district. This study revealed that as many as $56.8 \%$ of teenagers committed risky sexual behaviors such as hugging, hand-holding, oral kissing, masturbation, fondling, sexual intercourse, and petting. Another study done by Mahmudah, Yaunin, and Lestari (2016) in Padang revealed that as many as $79.1 \%$ of teenagers did not engage in risky sexual behavior, while the remaining $20.9 \%$ did. As many as $5.1 \%$ among those who engaged in risky sexual behavior also had sexual intercourse. Several other studies carried out in Indonesia showed that sexual attitudes and behaviors before marriage were more prominent in males than females (Faturochman, 1992; Rahyani et al., 2012; Fatoni and Situmorang, 2019; Aidil Firdauz, 2015; Itali Eze, 2014).

Bandura's Social Learning theory (1974) stated that human behavior can be divided into three categories that are related to one another, namely personal/individual factor, environmental factor, and behavioral factor. According to Alfiyah, Solehati, and Sutini (2018), (Moeliono, 2004) factors that can influence teenagers' behavior include internal factors (knowledge, attitude, and personality) and external factors (environment).

The research results showed that knowledge, attitude, personality, and environmental factors had an influence on teenagers' risky sexual behaviors. However, research on the relationship between the eight functions of family towards teenagers' risky 
sexual behavior is still very limited. Related to the aforementioned issue, further review and analysis need to be carried out in order to determine whether there is a relationship between family functions and teenagers' risky sexual behavior.

\section{RESEARCH METHOD}

\section{Data Source}

Analysis was done using secondary data from the Performance, Monitoring, and Accountability Survey 2018. The survey was carried out every year in order to measure the performance of population and family planning programs and family developments' (PPFPPFD) achievement, as stated on the Medium-Term National Development Plan (MTNDP) 2015 2019. This survey is on a national scale, which allows it to represent the provincially and nationally population with level parameter estimates.

The survey targets were the population of households, women of childbearing age aged 15-49 years, families, and unmarried adolescents aged 15-24 years. The approach used in this survey was the cluster approach (enumeration area). A cluster is a census block totaling about one or more census blocks that are close to each other and on one stretch, and number around 200 households. The sampling design was stratified multistage random sampling.

Based on the sample calculation conducted by the Central Bureau of Statistics, the number of clusters needed was 1,935 villages/sub-districts, distributed among 34 provinces and 514 districts/cities. The villages/sub-districts were clusters of enumeration areas allocated to each province based on urban and rural strata by considering the wealth index. Each cluster was selected using systematic random sampling of 35 households, and the final number of households interviewed was 66,616 households.

The sampling technique was carried out in several stages. The first stage consisted of selecting villages/sub-districts by means of a Probability Proportionate to Size (PPS) for sampling with a number of households (size) in the list of all villages/sub-districts. Village/sub-district sampling was carried out freely in rural and urban areas in districts/cities. The second stage was the selection of one cluster from each selected village/sub-district by PPS sampling according to the number of households (size) appointed to the selected cluster. The third stage was selecting 35 households carried out by systematic random sampling (SRS) based on the results of household listings compiled by interviewers in the selected cluster (BKKBN, 2018c).

The targets of the respondents in the 2018 PMA were households, women of childbearing age aged 15-49 years, families, male teenagers, and unmarried women aged 1524 years. All women of childbearing age aged 15-49 years from 35 households in each cluster were selected as samples. The total sample of women of childbearing age varied between each selected household and cross-cluster.

The data collection from the 2018 PMA utilized four questionnaires concerning household, family, women of childbearing age, and unmarried teenagers aged 15-24 years. The household questionnaire was the starting point from the series of PMA questionnaires because it identified the other target respondents from the list of households to determine women of childbearing age, families, and teenagers among the respondents. The enumerator (data collector) used smartphones as the data collection tool, which hosted a mobile collection (MOCO) application. Four types of questionnaires were available in this application and linked.

\section{Unit of Analysis}

This analysis used a family and teenager questionnaire. Family variables were needed in the merged youth questionnaire to allow the corresponding teenagers' family to be analyzed. There were as many as 22,210 teenage respondents aged 15-24 years old. Out of the total number of teenagers, 15,556 teenagers had had or currently had romantic partners. After combining the family questionnaire and the teenager questionnaire, 15,146 families were analyzed and indicated that each family could have more than one teenager. 


\section{Analysis Method}

This analysis was done to examine the roles of family on adolescent sexual risk behaviors in Indonesia. In order to determine these aspects, descriptive analysis methods and inferential analysis (univariate and bivariate) were used using binary logistic regression models. Descriptive analysis was presented in the form of frequency tabulations to determine the relationship between rows and columns. The inferential analysis used logistic regression to determine the effect of independent variables on the dependent variable. This allowed the most influential independent variables on the dependent variable to be seen. The IBM SPSS version 23 software was used for descriptive and inferential analyses.

\section{Variables}

The variable used in the analysis was family functions. The family functions consisted of socio-cultural, socializing and educational, affective, religious, protective, reproductive, environmental, and economical functions (The National Population and Family Planning Board, 2020). This analysis used one category to represent each family function related to teenagers' risky behaviors. Not all of the family functions were used in this analysis since not all of them related directly with teenagers' risky behavior. The functions applied in this analysis included the religious function (carrying out prayers), affective function (loyalty and trust), reproductive function (promiscuity), and socializing and educational functions (giving examples/becoming role models).

Dependent variables in this analysis were teenagers' premarital sexual behavior, which consisted of two categories: high-risk behaviors and low-risk behaviors. The category of high-risk behaviors included committing sexual intercourse and sexually arousing their partners, while the low-risk behaviors included holding hands, hugging, oral kissing, and not doing any of the high-risk activities. Teenagers' internal factors included teenagers' knowledge about KRR, information on PIK-R, and attitude towards sexual behavior. External factors included access to PIK-R through Instagram, Facebook, Twitter, and visits to the PIK-R's office, as well as socio- demographic factors (age, sex, education level, and residency). Parents' characteristics included community development for youth (CDY), knowledge on adolescents' reproductive health $(\mathrm{ARH})$, parents' practices in family functions, socio-demographics, and economic status. The head of the family's age was divided into three age categories, namely $\leq 34,35-49$, and $\geq 50$ years old. The categorization was based on the average age of parents being $\leq 34$ years when they started to have teenagers according to the PMA survey target in 2018. Teenagers were classified as those aged 15-24 years.

\section{RESULTS}

The results presented consist of univariate and bivariate analyses. Table 1 shows that as many as $94 \%$ of teenagers were at low-risk and $6 \%$ were at high-risk for risky sexual behavior. With as many as 15,556 teenagers as respondents, Table 2 provides the sociodemographic characteristics of teenagers, knowledge of ARH, and attitudes towards adolescent sexual behavior. In the category of sociodemographic characteristics, it was found that $55.1 \%$ teenagers lived in urban areas, $56.6 \%$ were male, $59.7 \%$ were in the $15-19$ age group, and most had a high school education.

Table 1. Distribution for Percentage of Teenagers' Risky Sexual Behavior Categories

\begin{tabular}{lccc}
\hline Variables & & $\mathbf{n}$ & \% \\
\hline $\begin{array}{l}\text { Risky } \\
\text { Categories }\end{array}$ & Low-Risk & 14,665 & 94.3 \\
\cline { 2 - 4 } & High-Risk & 891 & 5.7 \\
\hline Total & & $\mathbf{1 5 , 5 5 6}$ & $\mathbf{1 0 0}$ \\
\hline
\end{tabular}

Source: Processed data

Some of teenagers (94.5\%) had knowledge of ARH, while information about the Youth Information and Counseling Center (YICC) was only possessed by one in five teenagers.

Table 2 shows that as many as $98.2 \%$ of female teenagers disapproved of premarital sexual intercourse. The same opinion also came from the male teenagers, with as many as $97.5 \%$ of them disapproving of premarital sexual intercourse. Furthermore, three of ten teenagers 
Table 2. Indonesian Teenagers' Socio-Demographic, ARH Knowledge, Attitude Towards Risky Sexual Behavior, and Access to the YICC in 2018

\begin{tabular}{|c|c|c|c|}
\hline Socio-demographic Variables & Category & $\bar{n}$ & $\%$ \\
\hline \multirow{2}{*}{ Residencies } & City & 8,568 & 55.1 \\
\hline & Village & 6,988 & 44.9 \\
\hline \multirow[t]{2}{*}{ Gender } & Male & 8,811 & 56.6 \\
\hline & Female & 6,745 & 43.4 \\
\hline \multirow[t]{2}{*}{ Age Group } & $15-19$ & 9,282 & 59.7 \\
\hline & $20-24$ & 6,274 & 40.3 \\
\hline \multirow[t]{3}{*}{ Education } & $\leq$ Junior High & 3,414 & 21.9 \\
\hline & Senior High & 9,734 & 62.6 \\
\hline & College & 2,408 & 15.5 \\
\hline Total & & 15,556 & 100 \\
\hline \multicolumn{4}{|l|}{ Internal/ Individual } \\
\hline Knowledge & Category & & \\
\hline Knowledge on Adolescents & Yes & 14,702 & 94.5 \\
\hline Reproductive Health & No & 854 & 5.5 \\
\hline \multirow{2}{*}{$\begin{array}{l}\text { Knowledge on Youth Information } \\
\text { and Counseling Center (YICC) }\end{array}$} & Yes & 3,128 & 20.1 \\
\hline & No & 12,428 & 79.9 \\
\hline \multicolumn{4}{|l|}{ Attitude } \\
\hline \multirow[t]{2}{*}{ Female premarital sexual intercourse } & Approve & 276 & 1.8 \\
\hline & Disapprove & 15,280 & 98.2 \\
\hline \multirow[t]{2}{*}{ Male premarital sexual intercourse } & Approve & 386 & 2.5 \\
\hline & Disapprove & 15,170 & 97.5 \\
\hline Total & & $\mathbf{1 5 , 5 5 6}$ & 100 \\
\hline \multicolumn{4}{|l|}{ External } \\
\hline Access & Category & & \\
\hline \multirow{2}{*}{$\begin{array}{l}\text { Have accessed the YICC's social } \\
\text { media (Facebook, Instagram, } \\
\text { Twitter) }\end{array}$} & Yes & 943 & 30.2 \\
\hline & No & 2,185 & 69.8 \\
\hline \multirow[t]{2}{*}{ Have visited/used the YICC's office } & Yes & 884 & 28.2 \\
\hline & No & 2,245 & 71.8 \\
\hline Total & & 3,128 & 100 \\
\hline
\end{tabular}

Source: Processed data

were interviewed and stated that they have visited the YICC's social media such as Facebook, Twitter, and Instagram. Only three of ten teenagers had visited the YICC's office.

The results of other descriptive analysis showed that there were no significant differences in the families of teenagers living in urban areas $(54.9 \%)$ and rural areas $(45.1 \%)$. As many as $48.2 \%$ of teenagers' families were in the $35-49$ age group, while $48.5 \%$ were in the $>49$ age group. The education level of most of the families was middle (46.1\%) to lower education (46\%). Teenagers' parents mostly had jobs $(9.1 \%)$, but some were unemployed (8.4\%). $45.1 \%$ of families were upper-class, $19.4 \%$ were middleclass, and $35.5 \%$ were lower-class in terms of wealth. Most teenagers had a complete family structure (having a father and mother) (88.8\%), while the rest did not have a complete family structure.

The results showed that only one in ten of all teenagers' families participated in CDY. Meanwhile, $84.5 \%$ of families had heard, read, or seen information on ARH (fertile period and age at first marriage). The results of the survey related to the application of four family functions, namely the socializing and educational, reproductive, affective, and religious functions 
Table 3. Logistic Regression of Teenagers' Risky Sexual Behaviors

\begin{tabular}{|c|c|c|c|c|c|c|c|c|}
\hline \multirow[b]{2}{*}{ Variable } & \multicolumn{4}{|c|}{ Model I } & \multicolumn{4}{|c|}{ Model II } \\
\hline & B & S.E & Sig. & $\begin{array}{c}\text { OR } \\
(95 \% \mathrm{CI})\end{array}$ & B & S.E. & Sig. & $\begin{array}{c}\text { OR } \\
(95 \% \mathrm{CI})\end{array}$ \\
\hline \multicolumn{9}{|l|}{ City } \\
\hline Village & 0.10 & 0.24 & 0.67 & $1.11(0.70-1.76)$ & 0.19 & 0.12 & 0.09 & $1.21(0.97-1.52)$ \\
\hline \multicolumn{9}{|l|}{ Teenager } \\
\hline \multicolumn{9}{|l|}{ Female } \\
\hline Male & 1.31 & 0.24 & 0.00 & $3.72(2.33-5.93)$ & 0.99 & 0.13 & 0.00 & $2.70(2.09-3.47)$ \\
\hline \multicolumn{9}{|c|}{ Teenagers' Education } \\
\hline$\leq$ Junior High & & & 0.04 & & & & 0.05 & \\
\hline School & & & & & & & & \\
\hline Senior High & -0.26 & 0.34 & 0.45 & $0.77(0.40-1.50)$ & 0.13 & 0.14 & 0.35 & $1.14(0.87-1.48)$ \\
\hline College & 0.46 & 0.40 & 0.25 & $1.58(0.72-3.47)$ & 0.44 & 0.19 & 0.02 & $1.56(1.08-2.25)$ \\
\hline \multicolumn{9}{|l|}{ Teenagers' Age } \\
\hline \multicolumn{9}{|l|}{ Group (15-19) } \\
\hline Group (20-24) & 0.87 & 0.26 & 0.00 & $2.40(1.45-3.95)$ & 0.43 & 0.12 & 0.00 & $1.54(1.22-1.93)$ \\
\hline \multicolumn{9}{|c|}{ Teenagers Aware of ARH } \\
\hline \multicolumn{9}{|l|}{ No } \\
\hline Yes & 1.48 & 1.86 & 0.42 & $\begin{array}{l}4.41(0.12- \\
167.39) \\
\end{array}$ & -0.26 & 0.25 & 0.31 & $0.77(0.47-1.26)$ \\
\hline \multicolumn{9}{|c|}{ Teenagers Have Accessed YICC } \\
\hline No & 0.55 & 0.22 & 0.01 & $1.74(1.13-2.69)$ & & & & \\
\hline \multicolumn{9}{|l|}{ Yes } \\
\hline \multicolumn{9}{|c|}{ Teenagers' Attitude towards Females Having Premarital Sex } \\
\hline \multicolumn{9}{|l|}{ Disapprove } \\
\hline Approve & 1.45 & 0.52 & 0.01 & $\begin{array}{l}4.27(1.54- \\
11.85)\end{array}$ & 1.31 & 0.27 & 0.00 & $3.7(2.19-6.23)$ \\
\hline \multicolumn{9}{|c|}{ Teenagers' Attitude Towards Males Having Premarital Sex } \\
\hline \multicolumn{9}{|l|}{ Disapprove } \\
\hline Approve & 2.06 & 0.44 & 0.00 & $\begin{array}{l}7.81(3.31- \\
18.44)\end{array}$ & 2.53 & 0.21 & 0.00 & $\begin{array}{l}12.58(8.36- \\
18.95)\end{array}$ \\
\hline \multicolumn{9}{|c|}{ Age of the Head of Family } \\
\hline$\geq 50$ & & & 0.92 & & & & 0.00 & \\
\hline$\leq 34$ years old & 0.27 & 0.75 & 0.72 & $1.31(0.30-5.69)$ & 0.55 & 0.26 & 0.03 & $1.73(1.05-2.87)$ \\
\hline $35-49$ years old & 0.06 & 0.23 & 0.79 & $1.06(0.68-1.66)$ & -0.23 & 0.11 & 0.04 & $0.79(0.63-0.99)$ \\
\hline \multicolumn{9}{|c|}{ Sex of the Head of Family } \\
\hline \multicolumn{9}{|l|}{ Female } \\
\hline Male & 0.01 & 0.55 & 0.98 & $1.01(0.34-3.01)$ & -0.22 & 0.26 & 0.40 & $0.8(0.48-1.33)$ \\
\hline \multicolumn{9}{|c|}{ Education Level of the Head of Family } \\
\hline High & & & 0.01 & & & & 0.00 & \\
\hline Low & 1.58 & 0.54 & 0.00 & $\begin{array}{l}4.85(1.67- \\
14.11)\end{array}$ & 0.89 & 0.24 & 0.00 & $2.44(1.52-3.91)$ \\
\hline Middle & 1.52 & 0.52 & 0.00 & $\begin{array}{l}4.55(1.63- \\
12.69)\end{array}$ & 0.53 & 0.23 & 0.02 & $1.7(1.07-2.69)$ \\
\hline \multicolumn{9}{|c|}{ Occupation of the Head of Family } \\
\hline \multicolumn{9}{|l|}{ Unemployed } \\
\hline Employed & 0.01 & 0.40 & 0.97 & $1.01(0.46-2.24)$ & 0.34 & 0.21 & 0.11 & $1.4(0.92-2.13)$ \\
\hline
\end{tabular}




\begin{tabular}{|c|c|c|c|c|c|c|c|c|}
\hline \multirow[b]{2}{*}{ Variable } & \multicolumn{4}{|c|}{ Model I } & \multicolumn{4}{|c|}{ Model II } \\
\hline & B & S.E & Sig. & $\begin{array}{c}\text { OR } \\
(95 \% \mathrm{CI})\end{array}$ & B & S.E. & Sig. & $\begin{array}{c}\text { OR } \\
(95 \% \mathrm{CI})\end{array}$ \\
\hline \multicolumn{9}{|c|}{ New_Wealth_Index_the Head of Family } \\
\hline Lower & & & 0.11 & & & & 0.26 & \\
\hline Middle & -0.70 & 0.34 & 0.04 & $0.50(0.25-0.97)$ & -0.24 & 0.15 & 0.11 & $0.78(0.58-1.06)$ \\
\hline Upper & -0.34 & 0.27 & 0.21 & $0.71(0.42-1.21)$ & -0.14 & 0.13 & 0.29 & $0.87(0.67-1.13)$ \\
\hline \multicolumn{9}{|l|}{$\begin{array}{l}\text { Family } \\
\text { Structure }\end{array}$} \\
\hline \multicolumn{9}{|l|}{ Complete } \\
\hline Incomplete & 0.43 & 0.51 & 0.40 & $1.53(0.56-4.20)$ & 0.31 & 0.26 & 0.23 & $1.36(0.82-2.24)$ \\
\hline \multicolumn{9}{|c|}{ Parents' Activeness on CDY } \\
\hline \multicolumn{9}{|l|}{ No } \\
\hline Yes & 0.78 & 0.71 & 0.27 & $2.19(0.55-8.76)$ & 0.81 & 0.34 & 0.02 & $2.24(1.15-4.35)$ \\
\hline \multicolumn{9}{|c|}{ Awareness on ARH among the Head of Family } \\
\hline Yes & & & & & & & & \\
\hline No & 1.13 & 0.37 & 0.00 & $3.11(1.50-6.43)$ & & & & \\
\hline \multicolumn{9}{|c|}{ Religious Function [prayer] } \\
\hline \multicolumn{9}{|l|}{ Yes } \\
\hline No & 0.65 & 0.88 & 0.46 & $\begin{array}{l}1.91(0.34- \\
10.76)\end{array}$ & & & & \\
\hline \multicolumn{9}{|c|}{ Affective Function [Showing Love] } \\
\hline \multicolumn{9}{|l|}{ No } \\
\hline Yes & 0.20 & 0.28 & 0.48 & $1.22(0.70-2.12)$ & & & & \\
\hline \multicolumn{9}{|c|}{ Reproductive Function [Avoiding Promiscuity] } \\
\hline No & & & & & & & & \\
\hline Yes & 0.07 & 0.30 & 0.81 & $1.08(0.59-1.96)$ & 0.32 & 0.13 & 0.02 & $1.38(1.06-1.79)$ \\
\hline \multicolumn{9}{|c|}{ Socialization and Educational Function [Role models] } \\
\hline No & & & & & & & & \\
\hline Yes & 0.51 & 0.23 & 0.02 & $1.66(1.07-2.59)$ & & & & \\
\hline Constant & -7.98 & 2.08 & 0.00 & 0.00 & -4.88 & 0.49 & 0.00 & 0.01 \\
\hline
\end{tabular}

considered to be directly related to teenagers' risky behaviors. Three of the four functions were practiced by most families, namely the religious function $(98.9 \%)$, affective function $(72.2 \%)$, and reproductive function $(73.1 \%)$. The socializing and educational function was only carried out by around $41.6 \%$ of families.

The bivariate test showed that knowledge of ARH, opinions/attitudes of sexual intercourse between men and women, knowledge about YICC ( $\alpha=0.1 ; \alpha=0.05)$ had a significant effect on teenagers' risky behavior. In the same way, residence, sex, teenagers' age group, and education level ( $\alpha=$ $0.05)$ had a significant effect on teenagers' risky behaviors, while only access to YICC had no significant effect on teenagers' risky behavior. Teenagers who did not possess knowledge of ARH tended to approve premarital sexual intercourse, live in villages, never access the YICC, and never know about the YICC. Most of them were males in the 2024 age group, having an education level of below junior high school and being in the highrisk category.

Analysis of teenagers' parents showed that age, sex, educational level, occupational status, and economical status of the head of family significantly affected adolescents' risky behaviors. An adolescent tended to commit risky sexual behaviors when the head of the family was aged $\leq 34$ years, was female, had a low education level, and was unemployed. To conclude, this occurrence was found in adolescents whose family structure was not complete and who had low economic status. 


\section{DISCUSSION}

The results of the bivariate test showed that knowledge of ARH affected teenagers' risky sexual behaviors. This is similar to the findings of research conducted by Kyilleh, Tabong and Konlaan (2018), Sari and Yulianti (2020), and Rosdarni, Dasuki and Waluyo (2015) who found limited knowledge of reproductive health led to premarital sex being considered normal. A similar outcome was also found in a study conducted by Aidil Firdauz (2015), which stated that the prevalence of premarital sex behavior was more common in the male group than in the female group. Another study by Hidayangsih (2014) explained that some teenagers considered premarital sex normal and many male teenagers admitted that they were used to having sexual intercourse with several people for the purpose of pleasure. This is in line with research findings by Azinar (2013), who stated that teenagers' permissive and less permissive attitudes also affected teenagers' sexual behaviors. Furthermore, Rosdarni, Dasuki, and Waluyo (2015) also found that teenagers' permissive attitude led to five times greater tendency to engage in risky premarital sexual behaviors.

The bivariate analysis revealed that the teenagers' residence, sex, age group, and level of education had an influence on them engaging in risky sexual behaviors. This finding is similar to the results of research by Mahampang, Yaunin, and Lestari (2016) and Fatoni and Situmorang (2019), who found premarital sexual behavior was influenced by sex. However, this differs from the findings of Putri, Shaluhiyah, and Prabamurti (2017), which stated sex had no influence on premarital sexual behaviors.

The results of the bivariate test on family socio-demographic variables on teenagers' risky behaviors explicated that age, sex, education level, occupational status, and economic status of the head of family significantly influenced teenagers behaving at risk. An adolescent was more likely to engage in risky sexual behaviors when the head of the family was within the $\leq 34$ age category, sex who had a low educational level and low economic status, as well as was unemployed; further, their family structure was incomplete.
Some of these variables could be indicators for parents to prevent teenagers' risky sexual behaviors.

The National Population and Family Planning Board, as a government institution, has been continuously socializing the eight family functions in family life. Through this study, it became known that only parents who carried out reproductive health functions and parents who actively participated in CDY had a significant influence on their teenagers' risky sexual behaviors. The affective function did not significantly and directly affect risky sexual behavior. However, the number of parents who carried out the affective function by teaching their teenagers to avoid promiscuity tended to be smaller compared to the number of parents who did not. This showed that parents admitted to giving love to their teenagers, while teenagers felt that they received less love from their parents. The findings in this analysis were that the parents' activeness in CDY activities significantly affected teenagers' risky behavior. Adolescents whose heads of families actively participated in CDY activities (11.3\%) tended to engage in more risky behaviors than those who did not $(5.5 \%)$. Therefore, it can be assumed that the materials presented in CDY activities might not explain or socialize teenagers' risky behavior.

The results of the logistic regression analysis presented in Table 3 consist of two models. Model 1 (one) covered all variables analyzed for risky behavior variables. Model 2 (two) was a logistic regression model presented with significant variables in the bivariate test results that affected teenagers' risky behaviors. The first model showed male teenagers were 3.72 times more likely to behave at risk than female teenagers. This is in line with the research results of Suparmi and Isfandari (2016) which proved that the risk of premarital sexual behavior in male teenagers was 9.3 times greater than in female teenagers. Teenagers aged 20-24 years old also tended to be 2.4 times more likely to behave at risk than those aged 15-19 years old. Teenagers who had never had access to YICC tended to be 1.74 times to engage in risky behavior than teenagers who had never accessed YICC. This shows that the information provided on YICC 
activities could significantly reduce teenagers' risky behavior. The information provided, including information on reproductive health, the dangers of free sex, narcotics, and illegal drugs, increased knowledge among YICC members, especially teenagers.Research conducted by Rosdarni, Dasuki, and Waluyo (2015) also proved that teenagers with limited knowledge of reproductive health had 4.28 times the risk of engaging in risky premarital sexual activities. Meriyani, Yuli Kurniati and Januraga (2016) also supported this, but contrasted the result in terms of high parental income which affected teenagers' risky behavior. A publication by the World Health Organization (WHO) (2019) estimated that 3.9 million female aged 15-19 years from lower middle-income families had abortions every year. This supports the results of the bivariate test analysis after being controlled by sociodemographic variables in the results section.

Parents' awareness regarding the importance of adolescent reproductive health also significantly influenced teenagers to engage in risky sexual behaviors. Teenagers were 3.11 times more likely to engage in risky sexual behaviors when their parents were not aware of the importance of ARH in risky sexual behaviors. Results regarding access to information on the YICC were in accordance with the study of Ugoji (2014), which stated that teenagers who potentially behaved at risk were significantly influenced by the media and their self-esteem. The logistic regression also showed the opinion on premarital sexual behavior in males and females increased the risk of premarital sexual intercourse by 4.27 times and 7.8 times, respectively, when compared to those who disapproved it.

The findings in Table 3 show how family functions influenced teenagers' risky behavior. This proved that teenagers whose parents carried out socialization and education functions (parents become role models) and reproductive functions tended to have 1.66 times (model 1) and 1.38 times (model 2) the chance of committing risky sexual behavior, respectively. The findings of this analysis proved that parents did not fully teach their teenagers about ARH. Due to their teenagers' risky sexual intercourse, it seemed that parents became role models in educational and other social matters. Supposedly, if parents carried out educational and socialization functions as well as reproductive functions to their teenagers by teaching the importance of ARH and the dangers of risky sexual behavior from the beginning, it could be prevented. This is consistent with the research by Coley, Votruba-Drzal, and Schindler (2009). They argued that the relationship was carried out in a two-way manner between the family (parents) and teenagers against risky sexual activities in order to lower risky sexual behaviors.

The logistical analysis showed that the religious function did not directly influence teenagers' sexual behaviors. This is in accordance with the findings of Malinakova, K, Kopcakova, J, Geckova, AM, Van Dijk, JP, Furstova, J, Kalman, M, Tavel, P and Reijneveld, SA (2018) who stated that religious teachings had insignificant influence on risky sexual behavior. This is because the presence of religion without a strong understanding may not prevent a risky sexual behavior and may even increase it. This study emphasized the importance of family activities as a protective force for teenagers and showed that male parents could react differently from female parents in dealing with teenagers' risky behaviors.

\section{CONCLUSIONS AND SUGGESTIONS}

\section{Conclusions}

Based on the 2018 PMA, as many as $6 \%$ of all Indonesian teenagers were at high risk of risky premarital sexual behavior. Bivariate analysis of all the respondents' characteristics revealed that knowledge of $\mathrm{ARH}$, attitudes towards male and female sexual intercourse, knowledge of the YICC, residence, sex, age group, and education level had a significant impact on risky sexual behaviors. On the other hand, the result of logistic regression in model 1 showed that male teenagers tended to have 3.72 times the risk of risky behavior than female teenagers. The 20-24 age group also tended to have 2.4 times the risk of risky sexual behavior compared to the 1519 age group. Teenagers who had never accessed the YICC were 1.74 times more likely to commit risky sexual behavior compared to those who had accessed the YICC. The logistic regression also showed approval of premarital sexual intercourse 
in both sexes increased their risk of engaging in risky sexual behavior by 4.27 times and 7.8 times, respectively, compared to disapproval of it.

\section{Suggestions}

The findings in the analysis indicated the importance of parents' roles in preventing teenagers from engaging in risky behaviors, especially factors affecting the occurrence such as age, level of education, awareness of reproductive health, and knowledge of reproductive functions (avoiding promiscuity). Parent-based CDY activities are very important in optimizing their role in the community, in addition to socialization through Family Planning Extension and cadres to improve knowledge within the community, especially among parents. CDY activities need to be maintained to allow the ARH materials to be delivered optimally to parents with teenagers. The YICC is a place for teenagers to receive ARH materials, especially related to the prevention of risky sexual behavior, both through social media and direct activities in the field.

\section{REFERENCES}

Aidil Firdauz, M., 2015. Hubungan Antara Frekuensi Paparan Pornografi dengan Perilaku Seksual Pranikah Pada Remaja Sma/Sederajat di Wilayah Kerja Puskesmas Sukawati I Kabupaten Gianyar Bali 2014. Intisari Sains Medis, 2(1), pp.31-38.

Alfiyah, N., Solehati, T. and Sutini, T., 2018. Gambaran Faktor-Faktor yang Berhubungan dengan Perilaku Seksual Pranikah pada Remaja SMP. Jurnal Pendidikan Keperawatan Indonesia, 4(2), pp.131-139.

Azinar, M., 2013. Perilaku Seksual Pranikah Berisiko Terhadap Kehamilan Tidak Diinginkan. KEMAS: Jurnal Kesehatan Masyarakat, 8(2), pp.153-160.

Bandura, A., 1974. Behavior Theory and the Models of Man. American Psychologist, 29(12), pp.859-869.

Behulu, G.K., Anteneh, K.T. and Aynalem, G.L., 2019. Premarital Sexual Intercourse and Associated Factors among Adolescent Students in Debre-Markos Town Secondary and Preparatory Schools,
North West Ethiopia, 2017. BMC Research Notes, 12(1), pp.4-9.

BKKBN, 2013. Survei Demografi dan Kesehatan Indonesia 2012. Jakarta: BKKBN.

BKKBN, 2018a. Survei Demografi dan Kesehatan Indonesia 2017. Jakarta: $B K K B N$.

BKKBN, 2018b. Survei Kesehatan Reproduksi Remaja Indonesia (SKRRI) 2017. Jakarta: $B K K B N$.

BKKBN, 2018c. Survei Kinerja dan Akuntabilitas Program KKBPK (SKAP) 2018: Remaja. Jakarta: BKKBN.

BKKBN, 2020. Modul 2: Delapan Fungsi Keluarga. Jakarta: BKKBN.

BKKBN, 2017. Survei Kependudukan, Keluarga Berencana, Kesehatan Reproduksi Remaja dan Pembanguann Keluarga di Kalangan Remaja Indonesia. 2017: Remaja. Jakarta: BKKBN.

Coley, R.L., Votruba-Drzal, E. and Schindler, H.S., 2009. Fathers' and Mothers' Parenting Predicting and Responding to Adolescent Sexual Risk Behaviors. Child Development, 80(3), pp.808-827.

Dewi, A.P., 2012. Hubungan Karakteristik Remaja, Peran Teman Sebaya dan paparan Pornografi dengan perilaku Seksual Remaja di kelurahan Pasir Gunung Selatan Depok. Depok: Fakultas Ilmu Keperawatan Universitas Indonesia.

E.Ensminger, M., 1987. Adolescent Sexual Behavior As It Relates To Other Transition Behaviors in Youth. Risking the Future: Adolescent Sexuality, Pregnancy, and Childbearing, .

Eggleston, E., Jackson, J. and Hardee, K., 1999. Sexual Attitudes and Behavior among Young Adolescents in Jamaica. International Family Planning Perspectives, 25(2), pp.78-84.

Eze, I.R., 2014. Adolescents' attitude towards premarital sex. Mediterranean Journal of Social Sciences, 5(10 SPEC. ISSUE), pp.491-499.

Fatoni, Z. and Situmorang, A., 2019. Determinan Perilaku Berisiko Remaja Terkait Seksualitas di Era Globalisasi: Kasus Kota Medan. Jurnal Kependudukan Indonesia, 14(2), pp.137-152. 
Faturochman, 1992. Sikap dan Perilaku Seksual Remaja di Bali. Jurnal Psikologi, 1(1), pp.12-17.

Guha, Srimonti. 2013. Attitude,Knowledge and Behavior about Sexuality among IOSR Journal of Humanities And Social Science, 8(5), pp.05-19.

Kinsey, A.C., Pomeroy, W.B., Martin, C.E. and Gebhard, P.H., 1998. Sexual behavior in the human female. Indiana University Press.

Kyilleh, J.M., Tabong, P.T.N. and Konlaan, B.B., 2018. Adolescents' reproductive health knowledge, choices and factors affecting reproductive health choices: A qualitative study in the West Gonja District in Northern region, Ghana. BMC International Health and Human Rights, 18(1), pp.1-12.

Mahmudah, M., Yaunin, Y. and Lestari, Y., 2016. Faktor-Faktor yang Berhubungan dengan Perilaku Seksual Remaja di Kota Padang. Jurnal Kesehatan Andalas, 5(2), pp.448455.

Malinakova, K., Kopcakova, J., Geckova, A.M., Van Dijk, J.P., Furstova, J., Kalman,M., Tavel,P., Reijneveld,S. A.2018. I Am Spiritual, but not Religious": Does one without The Other Protect Against Adolescent Health-Risk Behaviour? International Journal of Public Health. 64(1), pp.115-124.

Meriyani, D.A., Yuli Kurniati, D.P. and Januraga, P.P., 2016. Risk Factors for Adolescent Pregnancy in Bali: Case Control Study. Public Health and Preventive Medicine Archive, 4(2), pp.201-206.

Moeliono, L., 2004. Seksualitas dan Kesehatan Reproduksi Remaja. Apa Masih Bisa Kita Lakukan. Majalah Kesehatan Perkotaan, 11, pp.30-41.
Organization, W.H., 2019. Adolescent pregnancy. World Health Organization.

Putri, S., Shaluhiyah, Z. and Prabamurti, P.N., 2017. Faktor-Faktor Yang Berhubungan dengan Perilaku Seksual Remaja yang Tinggal di Lingkungan Resosialisasi Argorejo Kota Semarang. Jurnal Kesehatan Masyarakat, 5(5), pp.10921101.

Rahyani, K.Y., Utarini, A., Wilopo, S.A. and Hakimi, M., 2012. Perilaku Seks Pranikah Remaja. Kesmas: National Public Health Journal, 7(4), pp.180-185.

Rosdarni, Dasuki, D. and Waluyo, S.D., 2015. Pengaruh Faktor Personal terhadap Perilaku Seksual Pranikah pada Remaja. Jurnal Kesehatan Masyarakat Nasional, 9(3), pp.214-221.

Hidayangsih, S.P., 2014. Perilaku Berisiko dan Permasalahan Kesehatan Reproduksi Pada Remaha. Jurnal Kesehatan Reproduksi, 5(2), pp.89-101.

Sari, L.Y. and Yulianti, S., 2020. Determinan Pengetahuan Remaja Terhadap Perilaku Seks Pranikah di SMKN X Jakarta Timur. Journal of Midwifery, 8(1), pp.23-28.

Suparmi, S. and Isfandari, S., 2016. Peran Teman Sebaya terhadap Perilaku Seksual Pranikah pada Remaja Laki-Laki dan Perempuan di Indonesia. Buletin Penelitian Kesehatan, 44(2), pp.139-146.

Ugoji, F.N., 2014. Determinants of risky sexual behaviours among secondary school students in Delta State Nigeria. International Journal of Adolescence and Youth, 19(3), pp.408-418.

UNICEF, 2006. Adolescent Development in East Asia and the Pacific: Realizing Their Potential. Adolescent Development And Participation Unit Programme Division. 